\title{
The role of social media in promoting political participation: The Lebanon experience
}

\section{Peran media sosial dalam mempromosikan partisipasi politik: Pengalaman Lebanon}

\author{
Muhammad Saud ${ }^{1 *}$, Dima Bassam El Hariri², \& Asia Ashfaq ${ }^{3}$ \\ ${ }^{1}$ Department of Sociology, Faculty of Social and Political Sciences, Universitas Airlangga \\ ${ }^{2}$ Faculty of Economic Science, Université Saint Joseph \\ ${ }^{3}$ Faculty of Humanities and Social Sciences, Bahria University \\ Address: ${ }^{1}$ Jalan Dharmawangsa Dalam, Airlangga, Surabaya, East Java, Indonesia 60286 \\ ${ }^{2}$ Damascus Mar Mikhaël BP 17-5208, Beirut 1104 2020, Lebanon \\ ${ }^{3}$ Sector E8 Shangrilla Road, Islamabad, Pakistan 44000 \\ E-mail: muhhammad.saud@gmail.com
}

Article History: Received 11 May 2020; Accepted 22 August 2020; Published Online 31 August 2020

\begin{abstract}
Social media, as part of the political experience, is an emerging trend in the sociology of youths and politics. The present study aimed to investigate the dynamic role of social media in the context of promoting political participation in Lebanese society. A quantitative survey method was used to collect the data from the field, and a total number of 260 questionnaires were filled in throughout the study. The study suggests that people are openly sharing their political opinions on social media platforms and that their expression rate in terms of sharing and learning political knowledge is increasing. The majority of respondents are using Facebook, Twitter, and Instagram for political purposes. The creation of social media has brought about an innovative advancement when it comes to individuals participating freely for political reasoning. Additionally, with exciting features and the freedom to share videos, pictures, and status updates, social media applications increasingly allow them to participate in political discussions. Where social media is providing opportunities for the public to participate in politics, electronic media is also facilitating a generation in terms of them gaining political knowledge from political talk shows. Social media's appropriateness for spreading something broad has triggered a contagious phenomenon that allows every notice polled to be accessed by everyone. It is possible to conclude that social media is suitable for use as an online political platform, and it provides an opportunity for the respondents to participate in the political sector of their country.
\end{abstract}

Keywords: role of social media; information technology; internet; political participation; Lebanon

\begin{abstract}
Abstrak
Penggunaan media sosial sebagai bagian dari pengalaman politik adalah tren yang muncul di bidang sosiologi pemuda dan sosiologi politik. Penelitian ini bertujuan untuk menyelidiki peran dinamis media sosial dalam mempromosikan partisipasi politik dalam masyarakat Lebanon. Metode survei kuantitatif digunakan untuk mengumpulkan data dari lapangan, dan total 260 kuesioner diisi sepanjang seluruh studi. Studi ini menunjukkan bahwa, orang secara terbuka berbagi pendapat politik mereka di platform media sosial, dan ekspresi mereka untuk berbagi dan belajar pengetahuan politik semakin meningkat. Mayoritas responden menggunakan Facebook, Twitter, dan Instagram untuk tujuan politik mereka. Media sosial telah membawa kemajuan inovatif yang membuat individu dapat berpartisipasi secara bebas dalam hal politik. Selain itu, dengan fitur-fitur menarik dan kebebasan untuk berbagi video, gambar, dan pembaruan status, aplikasi media sosial semakin memungkinkan mereka untuk berpartisipasi dalam diskusi politik. Di saat media sosial memberikan kesempatan kepada masyarakat untuk berpartisipasi dalam politik, media elektronik juga memfasilitasi suatu generasi dalam hal memperoleh pengetahuan politik dari talk show politik. Kesesuaian media sosial untuk menyebarkan sesuatu yang luas telah memicu fenomena menular yang memungkinkan setiap pemberitahuan dapat diakses oleh semua orang. Studi ini menympulkan bahwa media sosial cocok untuk platform politik daring, yang menyediakan kesempatan bagi responden untuk berpartisipasi dalam sektor politik negara tersebut.
\end{abstract}

Kata kunci: peran media sosial; teknologi informasi; internet; partisipasi politik; Lebanon 


\section{Introduction}

Everyone needs information to support their social or political activities in their regular life, aiming to access information as quickly as possible (Theocharis \& Lowe 2016). Information Technology (IT) has experienced the emergence of social media has followed a phase of development with the emergence of the internet. The use of social media allows an individual to interact, socialize, and communicate without the obstruction of space and time (Lilleker \& Koc-Michalska 2017, Bode \& Dalrymple 2016). Social media offers everyone interested the chance to participate by contributing and providing feedback openly, in addition to making comments, and sharing information in a fast and unlimited time-frame (Cai \& Zhou 2019).

Since its emergence, social media has been intended as a platform for its users to easily participate, share, and exchange information and ideas in virtual communities and networks. The facilities of social media include blogs, social networks, forums, and a visual world. Social media can be used as a form of online promotional media in the political marketing field where people can visit and read the information about politics and updates on political matters. Aside from that, it can be used as potential form of interactive promotional media to sensitize voters regarding political information on voting, campaigns, and events.

The term' political participation' is a part of a behavioral approach (political behavior) in political science. It has importance in the sociology of politics (Saud 2020, Kozman \& Cozma 2020). Political participation through social media platforms is unique, and it provides a better opportunity for people to participate in online spheres. In Lebanon, social media may encourage people to participate more freely, encouraged, and supported by a democratic climate. It guarantees that everyone can share their opinion and express their ideas on social media freely; however, people's participation through social media can act as a social agent and change politics' nature (Lee 2017, Daher et al. 2017, Paler et al. 2020). Thus, the electronic media characteristics specific to democratic changes may increase through Lebanon's social media activities, which have become very dynamic. The higher the rate of social media use, the higher the increase and impact on social movements and political change in Lebanon.

The context of democracy also influences individuals when they are conveying their views on social media. The most common platform is Twitter for stimulating political participation (Oni et al. 2017). Twitter is a type of social media platform that influences political change through the formation of public opinion, it has the feature of hashtags (Bode \& Dalrymple 2016, Bossetta et al. 2018, Berti 2019). The hashtag involves three forces at once, which localize the topic, focus the topic, and make it present within an easy internet-based search system. Because it takes place virtually with a limited sentence capacity, content on Twitter can share short bursts of political opinion. Various other platforms seek to increase political participation, including Facebook, Line, Instagram, WhatsApp, and others (Boulianne 2018, Saud et al. 2020).

The present study aimed to assess the significant contribution of social media platforms in support of political participation among internet-using Lebanese citizens. This study seeks to identify what social media platforms are usable and how they emerge as an essential participation tool. Social media's role plays an essential role in spreading information about social and political matters to the broader community in all fields.

\section{Research Method}

Creswell \& Poth (2016) stated that the methodology is a logical procedure that is part of the scientific process. It indicates the rules, principles, and procedures used to guide a scientific examination. The presented study was quantitative through a survey that was used to compile the data. The analysis and interpretation of the data in the present research will be discussed. The targeted population was individuals under the age of 35 years, and in terms of gender, both males and females from universal backgrounds participated, including those who had already or were currently participating in political activities. The data collection procedure was through an online Google Form directed at the students currently studying in the colleges, universities, and schools in Lebanon. The form 
comprised of 51 questions generated to approach the respondents in the Lebanese universities. A total of 260 respondents responded to the structured online questionnaire. The data compiled in Microsoft Excel, and it was further analyzed using SPSS v.25. Descriptive statistics were applied to get the frequency and percentage distribution.

\section{Results and Discussion}

\section{Demographic information}

The socio-demographic variable results (Table 1) show gender, age, education, family type, and the participants' monthly income in this study. It explains that the majority of the respondents in this study were young. We categorized age into three groups where each group has a different level of percentage. Thus, starting from $53.8 \%$, the majority were under the age of $21-25$ years old, while $43.1 \%$ were in the category of $25-30$ years old, and the remaining $3.1 \%$ were more than 30 years old. Therefore, the majority of young respondents were 21-25 years old. Table 1 also presents the gender category, where the majority (75\%) are male, and less than half $(25 \%)$ were female.

A family is a group of individuals related to one another by blood ties, marriage, or adoption, forming an economic unit. In the nuclear family system, the married couple lives with their children while in a joint and extended family, the married couple lives with one or even two of the family's earlier generations (Sultana 2017). The results show that less than half (46.9\%) had a joint family system while $40.8 \%$ were in a nuclear family system, and those in the extended family system totaled $12.3 \%$. Moreover, most of the respondents (55\%) were living in an urban area, while $45 \%$ had a rural background. The socio-demographic information shows the gross monthly family income of the respondents. The data show that almost one-third of the respondents (32.3\%) mentioned that their aggregate monthly family income from all sources was more than 800 USD while $25.4 \%$ had between 401-600 USD, 18.8\% had between 201-400 USD and 18.5\% had accumulated a monthly family income between 601 to 800 USD while the remaining (5\%) were in the category of below 20.000 USD.

It further explained the type of schooling and educational qualification of the respondents. The majority of the respondents (80.4\%) had education level up to a Master's degree and above, while $18.1 \%$ had graduated. In Lebanon, a Master's degree is equal to 18 years of education, and graduation is equal to 14 . The statistics show that almost half of the respondents $(47.7 \%)$ had gone through private schooling, $43.5 \%$ had studied in public educational institutes, and $8.8 \%$ fell into other. Here, 'other' means mixed schooling between both public and private educational institutes. According to the statistics in Table 1, most of the respondents are youngsters who are educated and have a diverse background in culture and society. Their political participation through social media could explain their level of activity. According to the gender variance, males are more active at participating in politics than females, which indicates the patriarchal characteristic of Lebanese society and male dominance in the public spheres of life.

\section{Opinion about the usage of social media for politics}

Social media provides information to the world (Harris et al. 2017); however, at the same time, it is facilitating the youngsters who are seeking to participate in the collection of information for a political purpose (Saud et al. 2020). According Table 2, half of the respondents (55\%) mentioned that most general types of information about political events, functions, or programs were usually collected from social media platforms regarding the opinion of using social media for political reasons. Another percentage (35.8\%) strongly agreed to collecting and learning about political events from social media applications. Youngsters regularly use their social media accounts to collect and follow their political leader's information, get updates, and discuss it. The statistics further indicate that most of the respondents $(56.5 \%)$ like to collect general information about their political representatives, political personalities, or political leaders. However, only $24.6 \%$ were likely to use social media platforms for political learning, specifically. 
Does social media support you participating in activities that you like to post, like, or comment on? It is the usual practice for political aspirants to respond with comments, posts and likes to react to the information provided. Table 2 further shows that more than one-third of the respondents $(39.6 \%)$ are likely to do this. The role of social media is not only about sharing information; however, it also solidifies the efficacy of social media users when it comes to politics (Ida et al. 2020). According Table 2, it can be concluded that most general (for open and analytical reasons) social media that is used for learning and participating for a political purpose may be supportive. It is what the present study respondents are most likely to use. In the current scenario, the strong participation in social media is widely selected as being a modern tool to engage and participate for a political purpose.

Table 1.

Socio-demographic variables

\begin{tabular}{|c|c|c|}
\hline Categories & Frequency & Percentage (\%) \\
\hline \multicolumn{3}{|l|}{ Age scale } \\
\hline $21-25$ & 140 & 53.8 \\
\hline $26-30$ & 112 & 43.1 \\
\hline Above 30 & 8 & 3.1 \\
\hline \multicolumn{3}{|c|}{ Monthly income in USD } \\
\hline Below 200 & 13 & 5.0 \\
\hline $201-400$ & 49 & 18.8 \\
\hline $401-600$ & 66 & 25.4 \\
\hline $601-800$ & 48 & 18.5 \\
\hline Above 800 & 84 & 32.3 \\
\hline \multicolumn{3}{|l|}{ Gender Status } \\
\hline Male & 195 & 75.0 \\
\hline Female & 65 & 25.0 \\
\hline \multicolumn{3}{|l|}{ Education level } \\
\hline Bachelor's & 51 & 19.6 \\
\hline Master's and above & 209 & 80.4 \\
\hline \multicolumn{3}{|l|}{ Type of schooling } \\
\hline Public & 113 & 43.5 \\
\hline Private & 124 & 47.7 \\
\hline Other & 23 & 8.8 \\
\hline \multicolumn{3}{|l|}{ Family type } \\
\hline Nuclear & 106 & 40.8 \\
\hline Joint & 122 & 46.9 \\
\hline Extended & 32 & 12.3 \\
\hline \multicolumn{3}{|l|}{ Resident status } \\
\hline Urban & 143 & 55.0 \\
\hline Rural & 117 & 45.0 \\
\hline Total & 260 & 100.0 \\
\hline
\end{tabular}

Source: Survey questionnaire

\section{Awareness of political knowledge}

In a democracy, awareness and learning are useful to gauge the candidates' personalities and characteristics, and it builds the capacity to select or choose the right candidates for the vacant political position (Margetts 2018). The results in Table 3 show that most respondents (62.5\%) agreed that watching television or reading a newspaper increases their interest in politics, which may also 
build the respondents' political awareness and knowledge; however, in terms of categorizing this value, $43.1 \%$ agreed to a great extent and $31.2 \%$ to some extent that learning about politics through watching television and media talk shows is useful. Table 3 also indicates that a considerable majority of the respondents $(65.1 \%)$ learn from online forums like 'democracy forum' when selecting their representative. The forums on social media provide the opportunity to discuss and share personal opinions regarding political matters. The purpose is to initiate political information for political efficacy, usually in countries where NGOs are working to strengthen the country's political structure.

Table 2.

Opinion regarding the use of social media

\begin{tabular}{lccc}
\hline \multicolumn{1}{c}{ Statement } & True & Somewhat & $\begin{array}{c}\text { Strongly } \\
\text { agreed }\end{array}$ \\
\hline Does social media provide information regarding political & 55.0 & 9.2 & 35.8 \\
events? & $(143)$ & $(24)$ & $(93)$ \\
Does social media help you to gain information about your & 56.5 & 24.6 & 18.8 \\
leaders? & $(147)$ & $(64)$ & $(49)$ \\
Does social media help you to participate in activities such & 35.8 & 39.6 & 24.6 \\
as posting, liking or commenting? & $(93)$ & $(103)$ & $(64)$ \\
\hline
\end{tabular}

Source: Survey questionnaire

Table 3.

To what extent can the respondents get an awareness of political knowledge?

\begin{tabular}{lccc}
\hline \multicolumn{1}{c}{ Statement } & $\begin{array}{c}\text { To great } \\
\text { extent }\end{array}$ & $\begin{array}{c}\text { To some } \\
\text { extent }\end{array}$ & $\begin{array}{c}\text { Not at } \\
\text { all }\end{array}$ \\
\hline Watching news channels increases your interest in politics & 43.1 & 31.2 & 25.8 \\
& $(112)$ & $(81)$ & $(67)$ \\
Online political forums (e.g. democracy forum) help me to select & 26.6 & 38.5 & 35.4 \\
political leaders & $(68)$ & $(100)$ & $(92$ \\
Generally, political candidates with more experience in politics & 36.9 & 44.6 & 18.5 \\
are productive for communities & $(96)$ & $(116)$ & $(48)$ \\
& 10.8 & 66.2 & 23.1 \\
Political marketing on social media increases both awareness & $(28)$ & $(172)$ & $(60)$ \\
and knowledge & & &
\end{tabular}

Source: Survey questionnaire

Generally, political candidates with more experience in politics are productive for communities (Rose-Redwood \& Rose-Redwood 2017). The statistics further indicate that most of the respondents $(81.5 \%)$ agreed with the selection of political candidates who have more experience in political activities or relevant background. Out of this high majority, $44.6 \%$ agreed to some extent, and $36.9 \%$ to a great extent. The remaining $(18.5 \%)$ were denied the selection of political candidates. In the traditional pattern of politics, older people use to participate because of their strong connections to the political affiliations; thus, the youngster should join the politics for making the change in society.

Political marketing on social media increases awareness and knowledge (Williams 2017). Thus a high proportion of the population (77\%) thought that political marketing is an excellent activity to learn. They can benefit from information about political events or political activities. It provides political knowledge as a form of public information to both intended voters and the general public. The results also show that around $11 \%$ agreed to some extent that political marketing is an awareness tool, whereas only $10.8 \%$ observed that they could learn from the political marketing ads in print, online or on social media.

It has been analyzed that considerable help, information, and motivation are achieved from watching political news shows, reading newspapers, and engaging with online political forums related to selecting political candidates and access to political knowledge in society. Furthermore, keeping the 
political experience as a focus cannot be a requirement for political candidacy as a whole. Therefore, other youngsters should avail of the chance to participate in the political sector. Along with the latest information technology advancements, social media has begun to take over the media's role as a proclaimer. The media is also participating as a social agent responsible for spreading the information that influences politics. It is because of the media failure is to play the role of proclaimer for the people traditionally. Thus they have begun to switch to a new medium of communication such as the internet and digital media (Underwood \& Ehrenreich 2017).

\section{Social media platforms for sharing political opinion}

The three (Facebook, Twitter, and Instagram) major social media platforms provide the opportunity to discuss political content or information in the online sphere. Table 4 shows that most of the respondents (88.8\%) agreed with the importance of using the most famous application, Facebook for sharing their political opinion. Out of this number, $48.8 \%$ strongly agreed that Facebook is a place where users can speak freely about their political opinion and learn. Forty percent only agreed somewhat, in that it is useful to share an opinion, and they can express themselves openly (mean $4.19>$ Facebook). The present results show social media - particularly Facebook - is unique, and it provides the platform through which users can like or create a page or group for any reason, be it for politics or another reason.

Table 4.

What kind of social media platforms are useful for political opinion?

\begin{tabular}{lcccccc}
\hline \multicolumn{1}{c}{ Statement } & SD & DA & $\mathbf{N}$ & $\mathbf{A}$ & SA & \multirow{2}{*}{ Mean } \\
& $\mathbf{1}$ & $\mathbf{2}$ & $\mathbf{3}$ & $\mathbf{4}$ & $\mathbf{5}$ & \\
\hline \multirow{2}{*}{ Does Facebook is useful for political opinion? } & 3.1 & 3.5 & 4.6 & 40.0 & 48.8 & 4.19 \\
& $(8)$ & $(9)$ & $(12)$ & $(104)$ & $(127)$ & \\
Does Twitter is useful for political opinion? & 6.2 & 8.1 & 21.9 & 36.5 & 27.3 & 3.80 \\
& $(16)$ & $(2.1)$ & $(57)$ & $(95)$ & $(71)$ & \\
Does Instagram is useful for political opinion? & 5.0 & 27.3 & 31.2 & 28.8 & 7.7 & 3.28 \\
& $(13$ & $(71)$ & $(81)$ & $(75)$ & $(20)$ & \\
\hline
\end{tabular}

Note: Strongly Agree: SA; Agree: A; Neutral: N; Disagree: DA; Strongly Disagree: SD

Source: Survey questionnaire

In the discussion of politics and online political activism, the contribution and usage of 'Twitter' indicate that it is useful and supportive of politicians and the general public when it comes to political information (Halberstam \& Knight 2016). The data further shows the more excellent value (63.8\%) of using 'Twitter' in that it is easy to use and follow the public figures of interest for political information. Furthermore, it also shows that $27.3 \%$ (mean 3.80> Twitter) strongly agreed that it is relatively easy to interact and learn about political information through 'Twitter.' Therefore, 'Tweeting' and 'Tweets' is now a typical social media trend used to collect information from public figures and political leaders (Engelmann et al. 2019).

Since the debate on political communication began, 'Instagram' is useful for spreading political knowledge in daily life (Badawy et al. 2018, Parmelee \& Roman 2019). The data further shows that most of the respondents (36.5\%) answered positively for sharing the view that 'Instagram' is useful for sharing political opinions. Political parties are increasingly using 'Instagram'to attract their followers or voters to the online sphere (mean 3.28>Instagram). Compared to 'Facebook' and 'Twitter, 'the use of 'Instagram' was relatively low. Therefore, the more frequent use of 'Facebook' and 'Twitter' might be useful for the respondents to participate online in political activities. It can be concluded from the above description that the right combination of social media platforms is essential to share opinions on the present political content. Moreover, social media platforms make it much easier to reproduce political posts or to share links. These are the factors that attract social media followers to using their platforms for political purposes (Bossetta 2018). 


\section{Conclusion}

The development of social media has brought about a renewal in sociology concerning politics and the sociology of youths. The present study was conducted in Lebanese communities where youths are increasingly using social media platforms for political purposes. The creation of Facebook, Twitter, Instagram, and others, for example, Myspace and LinkedIn, has brought about an innovative advancement when it comes to individuals participating freely for political reasoning. Additionally, with exciting features and the freedom to share videos, pictures, and status updates, social media applications increasingly allow them to participate in political discussions. Where social media is providing opportunities for the public to participate in politics, electronic media is also facilitating a generation in terms of them gaining political knowledge from political talk shows. Social media's appropriateness for spreading something broad has triggered a contagious phenomenon that allows every notice polled to be accessed by any and everyone.

This study concludes that most of the respondents are using Facebook and Twitter to participate in political activities. It is because of the ease of use of social media platforms. To some extent, educational background is a useful source of knowledge when it comes to demonstrating the frequent technology use in Lebanon. In light of the current research, the open-ended literature suggests a choice made to use social media platforms for political reasoning. As political parties use many tactics to gather people for their benefit, social media can be an excellent political efficacy source. According to the present study, the general public's activities result in the momentum of political change in Lebanese society. Therefore, the online sphere is not a way to learn and participate in the country's political characters; however, offline participation is also a good source of learning and practical participation.

\section{References}

Badawy A, Ferrara E, \& Lerman K (2018) Analyzing the digital traces of political manipulation: The 2016 Russian interference Twitter campaign. In: 2018 IEEE/ACM International Conference on Advances in Social Networks Analysis and Mining (ASONAM), 12 February, Barcelona, 258-265.

Berti B (2019) Rebel groups between adaptation and ideological continuity: The impact of sustained political participation. Government and Opposition 54 (3):513-535. https://doi.org/10.1017/ gov.2018.44.

Bode L \& Dalrymple KE (2016) Politics in 140 characters or less: Campaign communication, network interaction, and political participation on Twitter. Journal of Political Marketing 15 (4):311-332. https://doi.org/10.1080/15377857.2014.959686.

Bossetta M (2018) The digital architectures of social media: Comparing political campaigning on Facebook, Twitter, Instagram, and Snapchat in the 2016 US election. Journalism \& Mass Communication Quarterly 95 (2):471-496. https://doi.org/10.1177/1077699018763307.

Bossetta M, Segesten AD, \& Trenz H (2018) Political participation on Facebook during Brexit: Does user engagement on media pages stimulate engagement with campaigns? Journal of Language and Politics 17 (2):173-194. https://doi.org/10.1075/jlp.17009.dut.

Boulianne S (2018) Twenty years of digital media effects on civic and political participation. Communication Research 47 (7):947-966. https://doi.org/10.1177/0093650218808186.

Cai Y \& Zhou T (2019) Online political participation in China: Local government and differentiated response. The China Quarterly 238 (2019):331-352. https://doi.org/10.1017/ S0305741019000055.

Creswell JW \& Poth CN (2016) Qualitative Inquiry and Research Design: Choosing among Five Approaches. Sage publications.

Daher LA, Zantout R, \& Elkabani I (2017) User influence on Twitter hashtags evolution: A case study from career opportunities groups. In: 2017 International Conference on New Trends in Computing Sciences (ICTCS), 11-13 October, Amman, Jordan. 
Engelmann I, Kloss A, Neuberger C, \& Brockmann T (2019) Visibility through information sharing: The role of tweet authors and communication styles in retweeting political information on Twitter. International Journal of Communication 13:3569-3588.

Halberstam Y \& Knight B (2016) Homophily, group size, and the diffusion of political information in social networks: Evidence from Twitter. Journal of Public Economics 143 (2016):73-88. https://doi.org/10.1016/j.jpubeco.2016.08.011.

Harris PB, Mitchell SK, \& Mulroy MJ (2017) U.S. Patent Application No. 15/339,143.

Ida R, Saud M, \& Mashud M (2020) An empirical analysis of social media usage, political learning and participation among youth: A comparative study of Indonesia and Pakistan. Quality and Quantity 54 (2020):1285-1297. https://doi.org/10.1007/s11135-020-00985-9.

Kozman C \& Cozma R (2020) Lebanese television on Twitter: A study of uses and (dis) engagement. Journalism Practice 1-18. https://doi.org/10.1080/17512786.2020.1732832.

Lee SH (2017) Digital democracy in Asia: The impact of the Asian internet on political participation. Journal of Information Technology \& Politics 14 (1):62-82. https://doi.org/10.1080/193316 81.2016.1214095.

Lilleker DG \& Koc-Michalska K (2017) What drives political participation? Motivations and mobilization in a digital age. Political Communication 34 (1):21-43. https://doi.org/10.1080 $/ 10584609.2016 .1225235$.

Margetts H (2018) Rethinking democracy with social media. The Political Quarterly 90 :107-123. https://doi.org/10.1111/1467-923X.12574.

Oni AA, Oni S, Mbarika V, \& Ayo CK (2017) Empirical study of user acceptance of online political participation: Integrating civic voluntarism model and theory of reasoned action. Government Information Quarterly 34 (2):317-328. https://doi.org/10.1016/j.giq.2017.02.003.

Paler L, Marshall L, \& Atallah S (2020) How cross-cutting discussion shapes support for ethnic politics: Evidence from an experiment in Lebanon. Quarterly Journal of Political Science 15 (1):33-71. http://doi.org/10.1561/100.00018188.

Parmelee JH \& Roman N (2019) Insta-politicos: Motivations for following political leaders on Instagram. Social Media+ Society 5 (2). https://doi.org/10.1177\%2F2056305119837662.

Rose-Redwood C \& Rose-Redwood R (2017) Rethinking the politics of the international student experience in the age of Trump. Journal of International Students 7 (3):1-9. https://doi.org/ 10.32674/jis.v7i3.201.

Saud M (2020) Youth participation in political activities: The art of participation in Bhakkar, Punjab Pakistan. Journal of Human Behavior in Social Environment 30 (6):760-777. https://doi.org /10.1080/10911359.2020.1745112.

Saud M, Ida R, Abbas A, Ashfaq A, \& Ahmad AR (2020) The social media and digitalization of political participation in youths: An Indonesian perspective. Society 8 (1):83-93. https://doi. org/10.33019/society.v8i1.160.

Saud M, Ida R, \& Mashud M (2020) Democratic practices and youth in political participation: A doctoral study. International Journal of Adolescence and Youth 25 (1):800-808. https://doi.or $\mathrm{g} / 10.1080 / 02673843.2020 .1746676$.

Sultana S (2017) Social Networking Sites (SNS) and family relationship: A study on youths of Dhaka City. IOSR Journal of Humanities and Social Science 22 (4):46-52. https://doi. org/10.9790/0837-2204024652.

Theocharis Y \& Lowe W (2016) Does Facebook increase political participation? Evidence from a field experiment. Information, Communication \& Society 19 (10):1465-1486. https://doi.or g/10.1080/1369118X.2015.1119871.

Underwood MK \& Ehrenreich SE (2017) The power and the pain of adolescents' digital communication: Cyber victimization and the perils of lurking. American Psychologist 72 (2):144-158. https://doi.org/10.1037/a0040429.

Williams CB (2017) Introduction: Social media, political marketing and the 2016 US election. Journal of Political Marketing 16 (3-4):207-211. https://doi.org/10.1080/15377857.2017.1345828. 